\title{
Karakterisasi Minyak Atsiri dari Simplisia Basah Ranting dan Daun sebagai Alternatif Subtitusi Kulit Batang Cinnamomum burmannii Blume
}

\author{
Characterization of Essential Oil from Fresh Twigs and Leaves Simplicia \\ as an Alternative Substitution of Cinnamomum burmannii Blume's Bark
}

\author{
Mery Budiarti ${ }^{1 *}$, Wahyu Jokopriambodo ${ }^{1}$, Ani Isnawati ${ }^{2}$ \\ ${ }^{1}$ Balai Besar Penelitian dan Pengembangan Tanaman Obat dan Obat Tradisional (B2P2TOOT), Tawangmangu, \\ Jawa Tengah, Indonesia \\ ${ }^{2}$ Pusat Penelitian dan Pengembangan Biomedis dan Teknologi Kesehatan Dasar, Badan Litbang Kesehatan, \\ Jakarta, Indonesia \\ *Email : bsupriadi.mery@gmail.com
}

Diterima: 4 April 2018

Direvisi: 16 Juni 2018

Disetujui: 11 Agustus 2018

\begin{abstract}
Abstrak
Kulit batang Cinnamomum burmannii Blume merupakan bahan baku utama minyak kayumanis karena kadar sinamaldehidnya lebih tinggi dibandingkan bagian lainnya. Fakta tersebut mendorong terjadinya perilaku eksploitasi kulit batang Cinnamomum burmannii Blume tanpa disertai upaya budidaya sehingga dapat menimbulkan kelangkaan bahan baku. Ranting dan daun Cinnamomum burmannii Blume juga diketahui memiliki kandungan sinamaldehid sehingga berpotensi digunakan sebagai alternatif bahan baku penghasil sinamaldehid yang lebih efisien dibanding kulit batang. Penelitian ini mengkaji lebih dalam mengenai karakter minyak Cinnamomum burmannii Blume yang meliputi indeks bias, profiling komponen penyusun dan kadar senyawa penandanya, yaitu sinamaldehid. Pada penelitian ini digunakan tiga jenis sampel, yaitu simplisia basah kulit batang, ranting dan daun Cinnamomum burmannii Blume yang berasal dari dua lokasi tumbuh, Tawangmangu dan Purwokerto. Metode yang dilakukan dalam penelitian ini antara lain destilasi air sederhana, karakterisasi meliputi rendemen dan indeks bias menggunakan refraktometer, kemudian dilanjutkan analisis kualitatif dan kuantitatif dengan Thin Layer Chromatography (TLC) dan Gas Chromatography (GC). Hasil penelitian menunjukkan minyak Cinnamomum burmannii Blume yang berasal dari kulit batang, ranting dan daun memiliki profil yang berbeda, akan tetapi samasama memiliki sinamaldehid sebagai komponen utama. Bagian daun menghasilkan rendemen minyak yang lebih tinggi dibandingkan bagian ranting dengan kadar sinamaldehid yang mampu bersaing dengan kulit batang, yaitu $50 \%$ dari kadar sinamaldehid dalam minyak atsiri kulit batang.
\end{abstract}

Kata kunci: Cinnamomum burmannii Blume; minyak atsiri; destilasi air; sinamaldehid

\begin{abstract}
The bark of Cinnamomum burmannii Blume is the main raw material of Cinnamomum oil because its cinnamaldehyde content is higher than in the other parts. This condition lead to the exploitation of Cinnamomum burmannii Blume bark without any cultivation effort, thus it can cause the raw material scarcity. Twigs and leaves of Cinnamomum burmannii Blume are also known to contain cinnamaldehyde therefore it provide a potential alternative source of cinnamaldehyde. The purpose of this research is to investigate the characteristic of Cinnamomum burmannii Blume essential oil which includes refractive index, profiling of chemical constituent and percentage of cinnamaldehyde as a marker compound. This research used three fresh Cinnamomum burmannii Blume simplicia of bark, twigs and leaves from two selected growing locations: Tawangmangu and Purwokerto. Simple water distillation method was conducted, together with characterization and refractive index using refractometer, followed by qualitative and quantitative analysis with Thin Layer Chromatography (TLC) and Gas Chromatography $(G C)$. The results showed Cinnamomum burmannii Blume oil derived from bark, twig and leaf have different profiles, but all have cinnamaldehyde as the main component. The leaf produces higher essential oil yield percentage compared to the twig with a cinnamaldehyde content that is comparable to the bark by $50 \%$ of cinnamaldehyde content in cinnamomum bark oil.
\end{abstract}

Keyword: Cinnamomum burmannii Blume; essential oi; destilation; cinnamaldehyde 


\section{PENDAHULUAN}

Minyak kayumanis atau cinnamon oil merupakan minyak yang dihasilkan oleh tanaman Cinnamomum sp., salah satunya Cinnamomum burmannii Blume yang berasal dari Indonesia. Minyak ini merupakan salah satu jenis minyak atsiri yang sedang berkembang pesat di pasar global. Permintaan terhadap minyak atsiri tersebut selalu meningkat setiap tahunnya. Kondisi ini menunjukkan bahwa potensi pemanfaatan minyak kayumanis masih terbuka luas seiring dengan berkembangnya industri makanan, kosmetik dan obat. ${ }^{1}$ Cinnamomum burmannii Blume merupakan salah satu spesies dalam genus Cinnamomum famili Lauraceae yang merupakan tanaman asli Asia Tenggara dan umumnya digolongkan sebagai rempahrempah, tanaman hias, ataupun pohon hutan. Di Indonesia, Cinnamomum burmannii Blume dikenal juga dengan nama Indonesian Cassia atau padang cassia dan dalam bahasa Indonesia biasa disebut sebagai kayumanis. Pertumbuhannya paling banyak tersebar di Sumatra terutama Jambi, Jawa serta meluas hingga ke Timor. ${ }^{2}$

Cinnamomum burmannii Blume sudah lama dipercaya dapat mengobati berbagai penyakit, baik dalam pengobatan tradisional ataupun modern seperti kembung, mual, kolik, dispepsia, diare, demam, influenza, infeksi, arthritis dan rematik, hingga diabetes mellitus. ${ }^{3}$ Beberapa hasil penelitian lain juga menyimpulkan bahwa secara farmakologi, tanaman Cinnamomum burmannii Blume dapat memberikan efek karminatif, spasmolitik, antibakteri terhadap beberapa bakteri patogen, seperti $B$. cereus, $L$. monocytogenes, S. aureus, E. coli dan $S$. anatum, antifungi, antiinflamasi, penambah nafsu makan (stomakik) serta analgesik. ${ }^{4}$ Hingga saat ini, bahan baku untuk dapat memperoleh minyak atsiri yang umum digunakan pada tanaman Cinnamomum burmannii Blume adalah kulit batang, kulit dahan dan dahan. Hal ini kurang sejalan dengan beberapa hasil penelitian sebelumnya bahwa kandungan minyak atsiri Cinnamomum burmanni tersebar pada kulit batang, dahan, ranting, daun, kelopak bunga, akar dan biji. ${ }^{5,6}$

Komponen utama yang dikandung oleh Cinnamomum sp. adalah sinamaldehid, sinamat, asam sinamat dan beberapa jenis senyawa minyak atsiri seperti trans sinamaldehid, sinamil asetat, eugenol, Lborneol, kariopilen oksida, $\beta$-kariopilen, Lbornil asetat, $\alpha$-cubebene, $\alpha$-terpineol, terpinolen, dan $\alpha$-thujene. ${ }^{7,8}$ Kandungan senyawa kimia tersebut bervariasi tergantung pada beberapa faktor seperti bagian dari tumbuhan yang digunakan, umur tumbuhan, masa panen, lokasi tumbuh serta metode ekstraksinya. Senyawa kimia utama yang umum ditemukan pada minyak kayumanis antara lain sinamaldehid, eugenol, safrol, kumarin dan kamfor. Kuantitas ketiga senyawa tersebut berbeda pada setiap produk minyak kayumanis, tergantung bagian tumbuhan yang digunakan sebagai bahan baku. ${ }^{8,9,10,11}$ Haddi et al. (2017) mengemukakan bahwa hasil penelitian terdahulu umumnya minyak kayumanis yang berasal dari kulit batang lebih banyak mengandung sinamaldehid dan daun memiliki kandungan eugenol sebagai senyawa utama. Hasil penelitian terdahulu mengungkapkan minyak kulit batang terdiri atas sinamaldehid (65-80\%) dan eugenol (5$10 \%)$, sedangkan minyak daun terdiri atas eugenol (70-95\%) dan sinamaldehid (1$5 \%)^{7,9}$

Sinamaldehid berkontribusi terhadap aroma dan beragam sifat bioaktif dari Cinnamomum sp., sedangkan eugenol mampu meningkatkan aroma dan umum digunakan sebagai bahan pengawet alami. Keberadaan kedua senyawa kimia tersebut yang cukup dominan dalam minyak kayumanis digunakan sebagai parameter penelitian terkait tanaman Cinnamomum burmannii Blume. ${ }^{7,12}$

Mutu minyak kayumanis ditentukan oleh tinggi rendahnya kadar sinamaldehid, semakin tinggi kadar sinamaldehid semakin tinggi pula harganya. Sinamaldehid, senyawa aktif yang dapat diisolasi dari tanaman Cinnamomum sp, memiliki gugus aldehid aromatis yang diketahui memiliki 
aktivitas biologi dan farmakologi, seperti antikanker, antioksidan, antiinflamasi, antidiabetes, antimutagenik dan imunomodulator. ${ }^{13}$ Sebaliknya, kandungan eugenol dalam yang lebih tinggi dapat menurunkan kualitas dan harga minyak tersebut di pasaran. ${ }^{14}$

Seiring dengan kesadaran masyarakat akan manfaat sinamaldehid dalam minyak kayumanis untuk berbagai industri dan kesehatan, permintaan minyak tersebut menjadi meningkat. ${ }^{1,15}$ Fenomena tersebut mendorong terjadinya eksploitasi kulit batang Cinnamomum burmannii Blume tanpa upaya budidaya tanaman tersebut sehingga dikhawatirkan keberadaan tanaman ini akan semakin sedikit dan berujung pada kepunahan.

Penelitian mengenai minyak kayumanis, khususnya yang berasal dari Cinnamomum burmannii Blume masih terbatas sehingga nilai ekonomi minyak kayumanis Cinnamomum burmannii Blume masih lebih rendah dibandingkan Cinnamomum zeylanicum dan Cinnamomum cassia.${ }^{16}$ Data ilmiah terkait minyak kayumanis Cinnamomum burmannii Blume dengan bahan baku selain kulit batang juga masih sangat terbatas. Hal ini menyebabkan terbatasnya informasi ilmiah yang terperinci mengenai minyak kayumanis Cinnamomum burmannii Blume sehingga perkembangan pemanfaatan bagian selain kulit batang tumbuhan tersebut menjadi sangat lambat.

Informasi ilmiah merupakan faktor penting bagi peningkatan nilai ekonomi dari minyak atsiri. Informasi ilmiah tersebut dapat berupa profil minyak atsiri yang terkait dengan gambaran mutunya, meliputi karakteristik, identifikasi kualitatif dan kuantitatif komponen penyusun hingga kemampuan bioaktif minyak atsiri tersebut dalam berbagai bidang. ${ }^{17,18,19}$ Oleh karena itu, penelitian ini bertujuan mengkaji secara lebih mendalam mengenai profil Cinnamomum burmannii Blume, ditinjau dari produk Cinnamomum burmannii oil yang dihasilkan dari daun, ranting, dan kulit batang dalam bentuk simplisia basah. Hasil penelitian ini dapat digunakan sebagai informasi ilmiah mengenai profil minyak atsiri Cinnamomum burmannii Blume sehingga dapat dimanfaatkan untuk meningkatkan nilai ekonomi bagian ranting dan daun Cinnamomum burmannii Blume sebagai alternatif sumber sinamaldehid yang lebih efektif, efisien serta tidak mengancam kepunahan.

\section{METODE}

Penelitian observasional laboratorium ini dilakukan di Laboratorium Terpadu Balai Besar Penelitian dan Pengembangan Tanaman Obat dan Obat Tradisional (B2P2TOOT) Tawangmangu serta Laboratorium Quality Control PT. Tri Rahadja, Karangpandan.

\section{Alat dan bahan}

Bahan uji yang digunakan dalam penelitian ini meliputi daun, ranting dan kulit batang Cinnamomum burmannii Blume. Sampel tersebut dipreparasi di Laboratorium Terpadu Balai Besar Litbang Tanaman Obat dan Obat Tradisional (B2P2TOOT) Tawangmangu. Bahan lain yang digunakan antara lain standar sinamaldehid, plat Thin Layer Chromatography (TLC) silica F254, metanol absolut, etanol absolut, etil asetat, petroleum eter, diklorometan, asam format, akuades steril, etanol teknis 96\%, dan $\mathrm{Na}_{2} \mathrm{SO}_{4}$. Peralatan yang digunakan dalam penelitian ini di antaranya adalah seperangkat alat destilasi air, refraktometer, TLCDensitometer (CAMAG), Gas Chromatography (GC, Shimadzu) dan seperangkat alat gelas kimia.

\section{Prosedur kerja}

Tahapan penelitian ini meliputi pengambilan sampel tanaman Cinnamomum burmannii Blume yang dilakukan di dua lokasi, yaitu lereng Gunung Lawu, Kecamatan Tawangmangu, Kabupaten Karanganyar, Solo, dan lereng Gunung Slamet, Kecamatan Kebumen, Kabupaten Banyumas, Purwokerto; koleksi minyak atsiri dengan menggunakan metode destilasi air; pengamatan karakteristik minyak 
Cinnamomum burmannii Blume; penentuan profil minyak atsiri dan kadar sinamaldehid dengan TLC-Densitometer; serta profiling dan kuantifikasi sinamaldehid lebih lanjut pada sampel yang memiliki kadar sinamaldehid tertinggi dengan GC-MS.

\section{Persiapan bahan uji}

Sampel diperoleh dari dua lokasi tanam, yaitu kecamatan Tawangmangu, kabupaten Karanganyar, Solo dengan ketinggian \pm 680 mdpl dan Kecamatan Kebumen, kabupaten Banyumas, Purwokerto yang memiliki ketinggian \pm 1200 mdpl. Kedua lokasi tersebut dipilih karena daerah Tawangmangu merupakan lokasi utama pemasok bahan baku jamu di B2P2TOOT Tawangmangu, sedangkan daerah Purwokerto dikenal sebagai salah satu daerah pemasok Cinnamomum burmannii Blume untuk diekspor.

Daun, ranting dan kulit batang Cinnamomum burmannii Blume dipanen dari 2-3 individu tanaman sesuai dengan kebutuhan masing-masing. Selanjutnya, sampel tersebut disortasi, dibersihkan, dicuci, ditiriskan dan dipotong kecil dengan ukuran $\pm 1 \mathrm{~cm}$.

\section{Koleksi minyak atsiri}

Bahan uji ditimbang dengan neraca analitik sesuai berat yang ditentukan kemudian dimasukkan dalam alat destilasi air. Proses destilasi dilakukan menggunakan akuades sebagai media pelarut dengan perbandingan sampel dan media pelarut adalah $1: 10$. Destilasi dilakukan selama 5 10 jam dengan temperatur $100^{\circ} \mathrm{C}$ kemudian minyak atsiri yang dihasilkan dipisahkan dan dikeringkan (dihilangkan kandungan airnya) dengan menambahkan $\mathrm{Na}_{2} \mathrm{SO}_{4}$. Selanjutnya, minyak yang telah kering disimpan pada suhu $4^{\circ} \mathrm{C}$.

\section{Karakterisasi minyak atsiri \\ Minyak atsiri yang telah diperoleh masing-masing diukur volumenya menggunakan gelas ukur, kemudian ditimbang dan dibandingkan dengan bobot}

bahan kering yang digunakan untuk dihitung presentase rendemennya.

Indeks bias minyak atsiri ditentukan dengan menggunakan alat refraktometer.

Prosedur profiling dilakukan sesuai metode yang dijabarkan oleh Gopu, et al dengan sedikit modifikasi. ${ }^{20}$ Larutan pembanding yang mengandung sinamaldehid dengan kemurnian 96\%, masing-masing ditotolkan sebanyak $1 \mu \mathrm{L}$ pada plat TLC. Minyak atsiri diambil sebanyak $10 \mu \mathrm{L}$ dilarutkan, dimasukkan dalam labu takar $10 \mathrm{~mL}$ dan dicukupkan volumenya dengan metanol. Elusi dilakukan dengan fase gerak petroleum eterdiklorometana-asam format $(2: 4: 0,1)$, dikering-anginkan, dideteksi dan dikuantifikasi pada panjang gelombang 295 $\mathrm{nm}$ menggunakan TLC-Scanner. Larutan uji ditotolkan sebanyak $1 \mu \mathrm{L}$, kemudian dielusi dan dideteksi dengan cara yang sama dengan standar. Kadar sinamaldehid larutan uji dihitung dengan memplotkan luas area yang didapat pada persamaan regresi linier.

Profiling minyak atsiri dilakukan menggunakan GC sesuai dengan metode internal yang biasa dipergunakan oleh PT. Tri Rahardja, dengan kondisi sebagai berikut:

Kolom : Kapiler HP-5 (5,5-phenylmethylpolysiloane, nonpolar); $30 \mathrm{~m} \times 320 \mu \mathrm{m}$ $\times 0,25 \mu \mathrm{m}$

Pembawa : Gas hidrogen UHP (Ultra High Purity); laju alir 7,8 $\mathrm{mL} / \mathrm{min}$; constant flow

Temperatur : $130-160{ }^{\circ} \mathrm{C}$ at $5{ }^{\circ} \mathrm{C} / \mathrm{min}$ oven selama 3 menit $160-200{ }^{\circ} \mathrm{C}$ at $5{ }^{\circ} \mathrm{C} / \mathrm{min}$ selama 3 menit

Injektor : Split, $225^{\circ} \mathrm{C}$ Split ratio $15: 1$

Detektor : FID (Flame Ionized Detector), $250{ }^{\circ} \mathrm{C}$

Sampel $\quad: 1 \mu \mathrm{L}$

Internal : Metilbenzoat

standar 
Tabel 1 Karakteristik minyak kayumanis simplisia basah Cinnamomum burmanni Blume

\begin{tabular}{lrrrr}
\hline \multicolumn{1}{c}{ Asal sampel } & $\begin{array}{c}\text { Berat awal } \\
(\mathbf{k g})\end{array}$ & $\begin{array}{c}\text { Rendemen } \\
\text { minyak atsiri (\%) }\end{array}$ & $\begin{array}{c}\text { Kadar sinamaldehid } \\
(\%)\end{array}$ & Indeks bias \\
\hline Tawangmangu & & & & \\
$\quad$ Daun & 13,92 & 0,094 & 9,02 & 1,5065 \\
$\quad$ Ranting & 9,48 & 0,035 & 10,84 & 1,4535 \\
$\quad$ Kulit batang & 3,45 & 0,043 & 12,12 & 1,5265 \\
Purwokerto & & & & 1,5471 \\
$\quad$ Daun & 4,3 & 0,392 & 15,24 & 1,5080 \\
Ranting & 4,81 & 0,013 & 0,19 & 1,5497 \\
Kulit batang & 3,3 & 0,109 & 22,91 & \\
\hline
\end{tabular}

\section{HASIL DAN PEMBAHASAN}

\section{Karakteristik minyak atsiri}

Minyak atsiri Cinnamomum burmannii Blume diperoleh dari simplisia basah, terutama pada bagian daun, ranting dan kulit batang dengan berat seperti pada Tabel 1 . Karakteristik minyak atsiri Cinnamomum burmannii Blume dibagi menjadi beberapa kategori, yaitu rendemen dan indeks bias.

Tabel 1 menunjukkan perbandingan nilai rendemen minyak Cinnamomum burmannii Blume pada masing-masing jenis sampel, baik yang berasal dari Tawangmangu ataupun Purwokerto. Rendemen minyak Cinnamomum burmannii Blume yang berasal dari Purwokerto rata-rata memiliki nilai yang lebih tinggi dibandingkan Tawangmangu. Kondisi tersebut dapat dipengaruhi oleh perbedaan keadaan tempat tumbuh sampel. Hal tersebut membuktikan bahwa komposisi dan kadar minyak atsiri bergantung pada jenis tumbuhan, daerah tempat tumbuh beserta kandungan unsur hara di tanahnya, iklim dan bagian tumbuhan.

Hal ini sesuai dengan hasil yang diungkapkan oleh Ulfah dan Lucarda (2007), yakni tanaman Cinnamomum burmannii Blume yang tumbuh di daerah pegunungan memiliki kandungan minyak atsiri yang lebih rendah dibandingkan tanaman yang tumbuh di daerah dataran rendah dengan curah hujan sedikit. Tanaman yang memiliki lokasi tumbuh di daerah kekurangan air akan menghasilkan produk minyak atsiri yang lebih tinggi dibandingkan yang ditanam di lokasi dengan tingkat air yang berke- cukupan. Curah hujan pada dataran yang lebih rendah menyebabkan enzim yang berperan terhadap sintesis senyawa minyak atsiri lebih aktif, sehingga rendemen yang dihasilkan lebih besar. ${ }^{20,21}$

Kandungan minyak kayumanis yang berasal dari batang, kulit batang, dahan, kulit dahan, ranting, kulit ranting dan daun, baik secara kuantitas maupun komposisinya akan sangat bervariasi. Beberapa faktor yang berpengaruh antara lain perbedaan masa tanam yang berlaku untuk dahan dan daun, serta perbedaan pengambilan bagian (kulit batang dan xilem) untuk dahan dan ranting. ${ }^{6,11}$ Hasil penelitian menunjukkan daun memiliki nilai rendemen minyak kayumanis yang lebih tinggi dibandingkan kulit batang ataupun ranting. Hasil yang diperoleh ini tidak sebanding penelitian terdahulu yang mengungkapkan bahwa pada umumnya rendemen minyak atsiri pada daun basah adalah sebesar 0,2-0,38\% dan kulit batang basah 1,2-4,9\%. ${ }^{22}$ Daun merupakan bagian tanaman dengan jaringan penyusun yang lebih sederhana dibandingkan ranting dan kulit batang sehingga lebih mudah proses isolasinya. Sel minyak dan mucilago pada daun terletak dibawah lapisan epidermis diantara seluruh jaringan palisade dan parenkim berkarang. ${ }^{22,23}$ Sementara itu, ranting dan kulit batang cenderung lebih kecil produk minyak atsirinya karena anatomi jaringannya berbeda dengan daun, salah satunya memiliki dinding sel sebagai jaringan penyusunnya. Hal ini mengindikasikan bahwa produksi minyak Cinnamomum burmannii Blume akan lebih 
efisien apabila menggunakan daun sebagai bahan baku.

Nilai rendemen minyak atsiri ranting Cinnamomum burmannii Blume yang berasal dari Purwokerto lebih rendah dibandingkan Tawangmangu, sedangkan nilai rendemen untuk minyak atsiri daun dan kulit batang lebih tinggi. Salah satu faktor yang berpengaruh adalah perbedaan anatomi ranting dari kedua sampel yang digunakan. Ranting dan dahan Cinnamomum burmanni Blume secara anatomi terdiri atas kulit batang dan xilem, sebaliknya kulit batang hanya memiliki jaringan periderm, korteks dan floem. Kepadatan sel minyak pada tanaman yang berasal dari family Lauraceae, salah satunya Cinnamomum burmannii Blume lebih besar pada jaringan kulit batang dibandingkan xilem. ${ }^{11,24,25}$ Ranting Cinnamomum burmanni Blume yang berasal dari Purwokerto memiliki jaringan kayu yang lebih tebal dibandingkan Tawangmangu, sehingga sampel ranting tersebut diduga memiliki jaringan xilem yang lebih dominan daripada jaringan periderm, korteks dan floem yang mengandung banyak sel minyak. Oleh sebab itu, rendemen minyak yang dihasilkan oleh sampel ranting yang berasal dari Purwokerto lebih kecil dibandingkan sampel ranting dari Tawangmangu. Variasi struktur kulit, ranting dan dahan serta efek iklim selama pertumbuhan memiliki kontribusi terhadap komposisi dan kuantitas minyak kayumanis. ${ }^{11}$ Akan tetapi, fenomena ini perlu dilakukan studi lebih lanjut.

Faktor lain yang juga berpengaruh adalah perbedaan jenis komposisi senyawa dalam minyak ranting Cinnamomum burmannii Blume yang berasal dari Purwokerto dan Tawangmangu. Penelitian Deng et al (2014), memberikan hasil bahwa komponen utama yang menyusun minyak kayumanis yang berasal dari ranting adalah transsinamaldehid memiliki kelarutan dalam air yang tinggi. ${ }^{6}$ Penelitian ini metode destilasi yang digunakan adalah hidrodestilasi yang menggunakan air sebagai media pelarut minyak atsiri. Minyak ranting Cinnamomum burmannii Blume yang berasal dari Purwokerto diduga lebih banyak mengandung senyawa yang memiliki kelarutan tinggi dalam air daripada minyak ranting Tawangmangu. Keadaan tersebut dapat menyebabkan komponen minyak atsiri dari ranting Cinnamomum burmanni Blume yang berasal dari Purwokerto tidak teruapkan secara sempurna dan masih banyak yang terlarut dalam air sehingga menurunkan nilai rendemennya.

Indeks bias minyak atsiri berhubungan erat dengan komponen penyusun minyak atsiri yang dihasilkan. Nilai indeks bias pada minyak akan semakin meningkat jika minyak tersebut memiliki rantai karbon panjang dan terdapat sejumlah ikatan rangkap. ${ }^{26}$ Pada minyak Cinnamomum burmannii Blume, nilai ini sangat dipengaruhi oleh kandungan senyawa sinamaldehid dan terpenoid karena tergolong senyawa yang bersifat jenuh dan merupakan komponen terbesar dalam minyak Cinnamomum burmannii Blume. Perbandingan data indeks bias untuk masing-masing sampel minyak atsiri, yaitu daun, ranting dan kulit batang disajikan pada Tabel 1.

Minyak Cinnamomum burmannii Blume yang berasal dari Purwokerto memiliki nilai indeks bias yang lebih tinggi untuk masingmasing jenis sampel. Hal ini menunjukkan bahwa minyak atsiri yang berasal dari Purwokerto memiliki kandungan senyawa jenuh lebih tinggi dibandingkan Tawangmangu. Akan tetapi, dilihat dari hasil nilai indeks bias minyak atsiri, terdapat beberapa sampel yang belum dapat memenuhi standar minyak Cinnamomum burmannii Blume yang dipersyaratkan oleh SNI (Tabel 2). ${ }^{14}$ Fenomena tersebut dapat disebabkan oleh perbedaan metode destilasi, lokasi tumbuh sampel ataupun kemurniaan minyak atsiri. Oleh karena itu, masih perlu dilakukan permunian lebih lanjut pada sampel minyak atsiri yang telah dihasilkan pada penelitian ini. 
Tabel 2 Syarat mutu minyak kayumanis berdasarkan SNI

\begin{tabular}{cccl}
\hline No & \multicolumn{1}{c}{ Parameter } & Satuan & \multicolumn{1}{c}{ Persyaratan } \\
\hline 1. & Keadaan & & \\
& a. Warna & - & Kuning muda - coklat muda \\
& b. Bau & - & Khas kayumanis \\
2. & Bobot jenis $20^{\circ} \mathrm{C}$ & - & $1,008-1,030$ \\
3. & Indeks bias & - & $1,559-1,595$ \\
4. & Putaran optik & - & $\left(-5^{\circ}\right) \mathrm{s} / \mathrm{d}\left(0^{\circ}\right)$ \\
5. & Kelarutan dalam etanol & - & $1: 3$ larut dan jernih \\
6. & Kadar sinamaldehid & $\%$ & Min. 50 \\
\hline
\end{tabular}

Profiling minyak atsiri dan penentuan kadar sinamaldehid menggunakan $T L C$ Densitometer

Profiling dengan TLC bertujuan untuk mengetahui komponen penyusun minyak atsiri pada masing-masing sampel. Gambar 1 merupakan profiling dari sampel minyak Cinnamomum burmannii Blume simplisia basah daun, kulit batang dan ranting dari Purwokerto dan Tawangmangu.

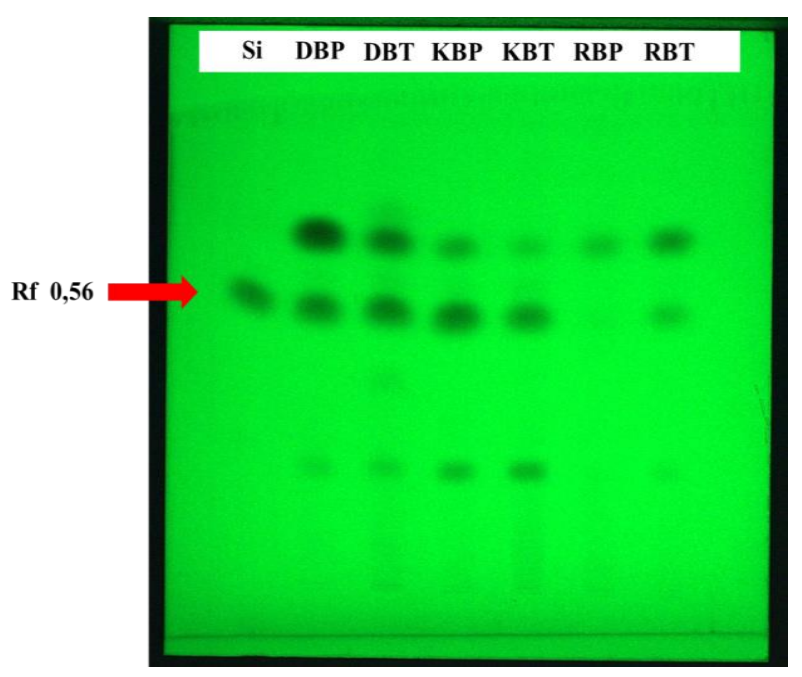

Gambar 1 Profil TLC minyak Cinnamomum burmannii Blume dari Tawangmangu dan Purwokerto pada UV 254 nm

Keterangan gambar:

$\mathrm{Si} \quad$ : Standar sinamaldehid

DBP : Daun basah Purwokerto

DBT : Daun basah Tawangmangu

KBP : Kulit batang basah Purwokerto

KBT : Kulit batang basah Tawangmangu

RBP : Ranting basah Purwokerto

RBT : Ranting basah Tawangmangu
Profiling minyak atsiri Cinnamomum burmannii Blume dilakukan dengan metode TLC pada panjang gelombang $254 \mathrm{~nm}$ dengan standar yang dipergunakan adalah Sinamaldehid (Gambar 1). Profil TLC komponen penyusun minyak atsiri simplisia basah kulit batang Cinnamomum burmannii Blume memiliki komposisi susunan senyawa yang lebih banyak dibandingkan daun dan ranting. Masing-masing sampel minyak atsiri simplisia basah Cinnamomum burmannii Blume, baik yang berasal dari Purwokerto ataupun Tawangmangu seluruhnya mengandung senyawa sinamaldehid. Akan tetapi, dalam profil tersebut tergambarkan bahwa kuantitas atau kadar sinamaldehid pada masing-masing minyak atsiri Cinnamomum burmannii Blume berbeda. Hal ini ditunjukkan oleh perbedaan intensitas noda dengan nilai $\mathrm{Rf}$ yang sama dengan standar sinamaldehid, yaitu dengan nilai $\mathrm{Rf} 0,56$. Nilai $\mathrm{Rf}$ yang didapat ini sesuai dengan penelitian yang telah dilakukan sebelumnya oleh $\mathrm{Wu}$, et.al. (2014) bahwa secara berurutan nilai $\mathrm{Rf}$ untuk asam sinamat 0,15 ; sinamat alkohol 0,28; koumarin 0,39; 2-metoksi sinamaldehid 0,51 dan sinamaldehid $0,56 .^{27}$

Tabel 1 menampilkan rata-rata kadar sinamaldehid dalam minyak atsiri Cinnamomum burmannii Blume pada masing-masing simplisia daun, ranting dan kulit batang, baik yang berasal dari Tawangmangu ataupun Purwokerto.

Data tersebut menunjukkan bahwa ratarata kadar sinamaldehid tertinggi pada 
minyak atsiri Cinnamomum burmannii Blume, baik yang berasal dari Purwokerto ataupun Tawangmangu terdapat pada kulit batang. Hal ini sesuai dengan hasil penelitian terdahulu, bahwa sinamaldehid tertinggi terdapat pada minyak atsiri kulit batang Cinnamomum burmannii Blume..$^{6,7,11}$ Sinamaldehid merupakan senyawa yang banyak terdapat pada kulit batang karena memiliki fungsi sebagai senyawa pendukung pertumbuhan lignin atau zat kayu.

Daun memiliki kandungan sinamaldehid tertinggi kedua setelah kulit batang dari Purwokerto sehingga kedua sampel tersebut dilakukan analisis lebih lanjut menggunakan Gas Chromatography, baik secara kualitatif ataupun kuantitatif. Data tersebut sesuai dengan beberapa penelitian yang telah dilakukan berhasil mengidentifikasi komponen utama dalam minyak atsiri daun Cinnamomum burmannii Blume adalah sinamaldehid, hal ini juga berlaku pada minyak atsiri kulit batang. Sedangkan, pada minyak atsiri kulit ranting komponen penyusun utamanya adalah transsinamaldehid sebesar $80 \%$ dan senyawa sinamaldehidnya hanya sebesar $0,9 \%{ }^{28}$

\section{Profiling minyak atsiri dan penentuan kadar sinamaldehid dari daun dan kulit batang Cinnamomum burmannii Blume menggunakan GC}

Profiling dilanjutkan dengan menggunakan GC yang memiliki sensitifitas lebih tinggi untuk sampel volatil seperti minyak atsiri. Oleh karena itu, metode tersebut dipilih untuk menentukan komponen penyusun serta kadar sinamaldehid kedua sampel terpilih, yaitu minyak atsiri kulit batang dan daun yang berasal dari Purwokerto.

$\begin{array}{lcr}\text { Profil GC } & \begin{array}{c}\text { diperoleh } \\ \text { membandingkan }\end{array} \text { puncak-puncak } & \text { yang } \\ \text { muncul pada } & \text { kromatogram } & \text { standar } \\ \text { sinamaldehid } & \text { dan sampel. } & \text { Pada } \\ \text { kromatogram standar (Gambar } & \text { 2) } & \text { dapat } \\ \text { dilihat bahwa puncak sinamaldehid muncul } \\ \text { pada menit ke-10. }\end{array}$

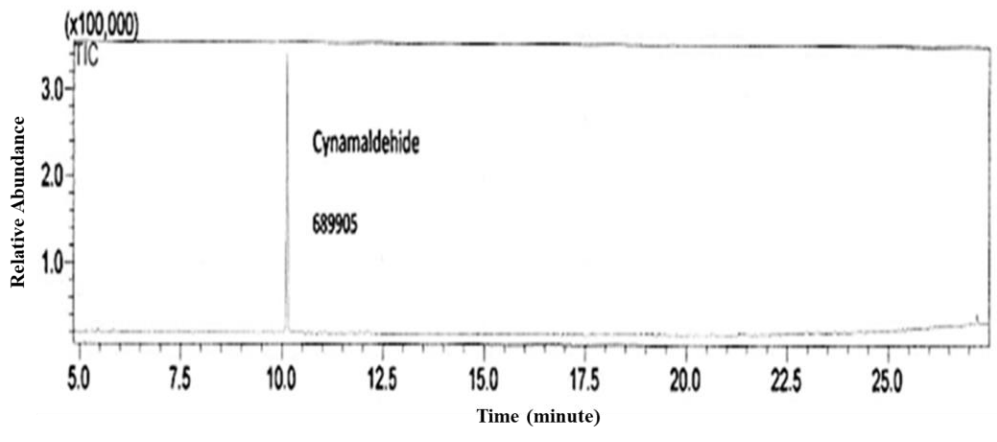

\section{Gambar 2 Profil GC standar sinamaldehid}

Gambar 3 menunjukkan menunjukkan perbandingan puncak yang muncul pada krpmatogram sampel minyak atsiri kulit batang dan daun. Minyak atsiri simplisia basah kulit batang Cinnamomum burmannii Blume yang berasal dari Purwokerto tersusun atas beberapa komponen senyawa, salah satu yang tertinggi adalah sinamaldehid (waktu retensi 10,15) serta terdapat tiga senyawa lain yang menonjol, yaitu dengan waktu retensi 12,60;10,40 dan 9,35 menit.

Minyak atsiri simplisia basah daun juga mengandung senyawa sinamaldehid (waktu retensi 10,05) sebagai komponen penyusun utamanya, kemudian disusul oleh dua senyawa lain yang menonjol, yaitu pada waktu retensi 12,05 dan 10,10. Berdasarkan kedua kromatogram tersebut, dapat disimpulkan bahwa komponen senyawa penyusun minyak atsiri simplisia basah kulit batang dan daun memiliki kemiripan satu dengan lain, yakni keduanya mengandung senyawa sinamaldehid. Perbedaan antara kedua kromatogram tersebut terletak pada nilai intensitas pincak dan luas area, baik untuk sinamaldehid ataupun komponen senyawa penyusun lainnya.

Luas area sinamaldehid pada minyak atsiri simplisia basah kulit batang lebih besar dibandingkan daun, yaitu \pm 2 kali lipatnya. Hal ini mendukung data sebelumya, yaitu hasil penentuan kadar sinamaldehid dengan metode TLC-densitometer. 

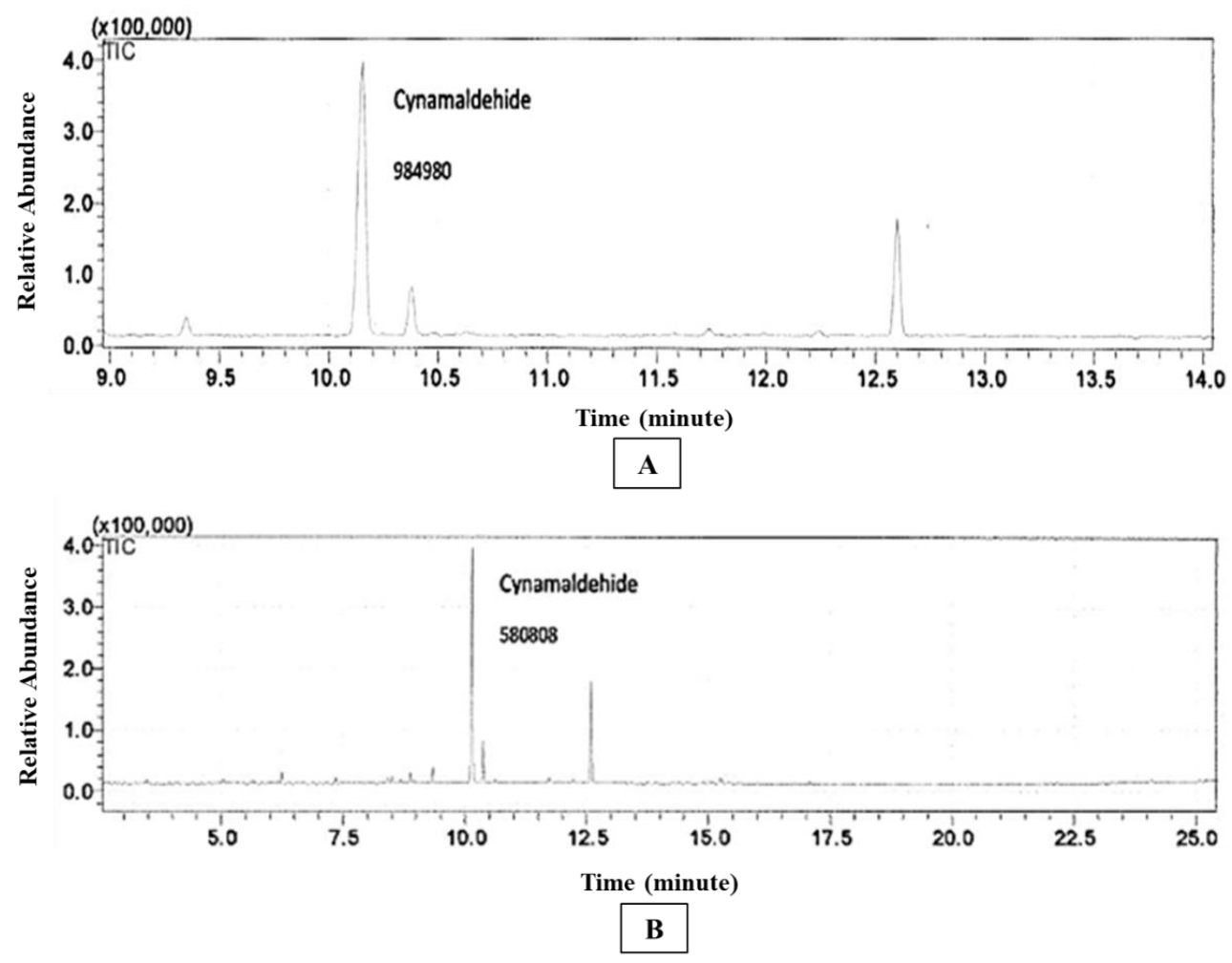

\section{Gambar 3 Perbandingan profil GC sampel minyak atsiri (A) kulit batang dan (B) daun Cinnamomum burmannii Blume yang berasal dari Purwokerto}

Tabel 3 menunjukkan bahwa kadar sinamaldehid pada minyak atsiri simplisia basah kulit batang Cinnamomum burmannii Blume lebih tinggi dibandingkan daun. Kadar sinamaldehid dalam simplisia basah kulit batang yang berasal dari Purwokerto masih lebih rendah dibandingkan dengan hasil penelitian yang telah ada, yaitu $69,3 \%$. Hal ini dapat dipengaruhi oleh beberapa faktor, seperti metode destilasi yang dipergunakan dan lokasi tumbuh tanaman. Menurut Yuliarto, dkk (2012), metode destilasi juga dapat berpengaruh pada komposisi minyak atsiri sebab proses ekstraksi minyak atsiri dengan destilasi melibatkan peningkatan suhu. Metode destilasi air mengalami peningkatan suhu yang relatif lebih tinggi dibandingkan dengan destilasi uap-air sehingga reaksi dekomposisi minyak sangat mungkin terjadi. Selain itu, pada destilasi air, minyak atsiri akan terbawa oleh media pembawa (air), kemudian akan menguap bersama setelah proses pemanasan. Proses tersebut yang menyebabkan beberapa kandungan minyak atsiri masih terlarut dalam air, sehingga rendemen yang dihasil tidak maksimal. ${ }^{27,28}$

\section{Tabel 3 Perbandingan kadar sinamaldehid} secara GC

\begin{tabular}{clcc}
\hline No & Sampel & Volume (mL) & Kadar (\%) \\
\hline 1 & Kulit batang & 25 & 54,973 \\
2 & Daun & 25 & 30,725 \\
\hline
\end{tabular}

Perbandingan nilai kadar sinamaldehid pada kulit batang dan daun adalah $2: 1$. Informasi tersebut dapat menjadi dasar ilmiah mengenai konversi bahan baku penghasil sinamaldehid selain kulit batang Cinnamomum burmannii Blume. Daun merupakan salah satu alternatif bahan substitusi kulit batang, karena rendemen minyak atsiri yang dihasilkan oleh daun tinggi dibandingkan kulit batang (Gambar 1). Akan tetapi, apabila daun digunakan sebagai sumber sinamaldehid maka perlu dilakukan penyetaraan kebutuhan simplisia daun terhadap kadar sinamaldehid yang dihasilkan oleh daun. 


\section{KESIMPULAN}

Karakter minyak atsiri Cinnamomum burmannii Blume ditentukan berdasarkan nilai rendemen dan indeks bias ketiga jenis minyak atsiri, yaitu yang berasal dari kulit batang, ranting dan daun. Nilai rendemen minyak atsiri Cinnamomum burmannii Blume tertinggi terdapat pada bagian daun, sedangkan untuk nilai indeks bias, agar dapat memenuhi persyaratan SNI diperlukan proses permunian. Berdasarkan profil minyak atsiri Cinnamomum burmannii Blume dari daun, ranting, kulit batang dengan metode TLC-densitometer dan GC semuanya menunjukkan keberadaan sinamaldehid sebagai senyawa penyusun utama. Kadar sinamaldehid pada minyak atsiri Cinnamomum burmannii Blume tertinggi terdapat dalam kulit batang, diikuti oleh daun dan ranting. Sampel Cinnamomum burmanni Blume yang berasal dari Purwokerto memiliki kandungan sinamaldehid yang lebih tinggi. Analisis lanjut menggunakan GC pada minyak atsiri simplisia basah kulit batang dan daun Cinnamomum burmannii Blume asal Purwokerto menunjukkan bahwa kadar sinamaldehid pada daun adalah setengah kali dari kulit batang, sehingga berpotensi sebagai alternatif subtitusi sumber sinamaldehid.

\section{SARAN}

Daun Cinnamomum burmannii Blume diharapkan dapat digunakan sebagai alternatif bahan baku penghasil Cinnamomum oil menggantikan kulit batang. Berdasarkan hasil penelitian ini, daun Cinnamomum burmannii Blume dinilai cukup efisien dan efektif sebagai sumber sinamaldehid, salah satu senyawa penting dalam Cinnamomum oil. Selain itu, perlu dilakukan pula penentuan kadar eugenol dalam minyak atsiri yang dihasilkan agar dapat diketahui secara pasti kualitas dari Cinnamomum oil tersebut. Hal ini sesuai dengan acuan standar dari the Essential Oil Association of USA terkait kualitas minyak kayumanis.

\section{UCAPAN TERIMAKASIH}

Terimakasih kami ucapkan kepada Badan Penelitian dan Pengembangan Kesehatan selaku penyandang dana utama penelitian ini melalui program Risbinkes 2016 dan pembimbing atas bantuan dan kerjasamanya selama penelitian ini berlangsung. PT. Tri Rahardja, Karangpandan yang telah memberikan kemudahan dalam proses pengujian sampel. Endang Brotojoyo, A.Md, Kumiati, S.Si, Zulaikah Tri Hastuti, A.Md dan Nunik Dina Merdekwati, staf Laboratorium Terpadu dan Pasca Panen B2P2TOOT Tawangmangu yang telah membantu pelaksanaan dan penyelesaian kegiatan penelitian ini.

\section{DAFTAR RUJUKAN}

1. Inggrid $\mathbf{M}$, Djojosubroto $H$. Destilasi uap minyak atsiri dari kulit dan daun kayu manis (Cinnamomum burmannii). Jurnal Universitas Katholik Parahyangan. 2008;1:1-16.

2. Izyani FA, Susanti D, Taher M. Antimicrobial activity and synergic effect of Cinnamomum burmannii's essential oil \& its isolated compound (cinnamaldehyde). In: International Conference on Chemical, Agricultural and Medical Sciences. Kuala Lumpur: International Institute of Chemical, Biological, and Environmental Engineering; 2013. p. 26-9.

3. Abdelwahab SI, Mariod AA, Taha MME, Zaman FQ, Abdelmageed AHA, Khamis S, et al. Chemical composition and antioxidant properties of the essential oil of Cinnamomum altissimum Kosterm. (Lauraceae). Arabian Journal of Chemistry. King Saud University; 2014.

4. Badan Pengawas Obat dan Makanan RI. Manfaat yang berguna dari kayu manis. Naturakos. 2009;4(11):10-1.

5. Menggala SR, Damme P V. Improving Indonesian Cinnamon (C. burmannii (Nees \& T. Nees) Blume) value chains for greater farmers incomes. In: IOP Conference Series: Earth and 
Environmental Science [Internet]. Surakarta: IOP Publishing; 2018. p. 1-5. Available from: http://iopscience.iop.org/article/10.1088/ 1755-1315/129/1/012026

6. Deng X, Liao Q, Xu X, Yao M, Zhou Y, Lin $M$, et al. Analysis of essential oils from cassia bark and cassia twig samples by GC-MS combined with multivariate data analysis. Food Analytical Methods. 2014;7(9):1840-7.

7. Rao PV, Gan SH. Cinnamon: A multifaceted medicinal plant. Eveidence-Based Complementary and Alternative Medicine. Hindawi Publishing Corporation; 2014;2014:112.

8. Al-Dhubiab BE. Pharmaceutical applications and phytochemical profile of Cinnamomum burmannii. Pharmacognosy Reviews. 2012;6(12):125-31.

9. Haddi K, Oliveira E, Faroni LR. Cinnamon Oil. In: Nollet LML, Rathore HS, editors. Green pesticides handbook : Essential oils for pest control. CRC Press; 2017. p. 117-50.

10. Paranagama $\mathrm{P}$, Wimalasena $\mathrm{S}$, Jayatilake G, Jayawardena A, Senanayake U, Mubarak A. A comparison of essential oil constituents of bark, leaf, root and fruit of cinnamon (Cinnamomum zeylanicum Blum) grown in Sri Lanka. Journal of National Science Foundation Sri Lanka. 2002;29(3\&4):147-53.

11. Geng S, Cui Z, Huang X, Chen Y, Xu $\mathrm{D}$, Xiong P. Variations in essential oil yield and composition during Cinnamomum cassia bark growth. Industrial Crops and Products. 2011;33:248-52.

12. Khasanah LU, Anandhito BK, Uyun Q, Utami R, Manuhara GJ. Optimasi proses ekstraksi dan karakterisasi oleoresin daun kayu manis (Cinnamomum burmanii) dua tahap. Indonesian Journal of Essential Oil. 2017;2(1):20-8.

13. Lin L-T, Wu S-J, Lin C-C. The anticancer properties and apoptosis- inducing mechanisms of cinnamaldehyde and the herbal prescription Huang-Lian-Jie-Du-Tang (Huáng Lián Jiě Dú Tang) in human hepatoma cells. Journal of Traditional and Complementary Medicine. Elsevier Masson SAS; 2013;3(4):227-33.

14. Standar Nasional Indonesia. SNI 063734-2006, ICS 71.100.60. Jakarta;

15. Widiyanto A, Siarudin M. Karakteristik daun dan rendemen minyak atsiri lima jenis tumbuhan kayu putih. Jurnal Penelitian Hasil Hutan. 2013;31(4):23541.

16. Singh P, Bajpai M, Prakash O, Tiwari R, Mathur S, Singh RM, et al. High performance thin layer chromatographic method for the determination of cinnamaldehyde in Cinnamomum zeylanicum Bark powder. Journal of Natural Remedies. 2008;8(2):179-82.

17. Salleh WMNH, Ahmad F, Yen KH, Zulkifli RM. Essential oil compositions of Malaysian Lauraceae: A mini review. Pharmaceutical Sciences [Internet]. 2016;22(1):60-7. Available from:

http://journals.tbzmed.ac.ir/PHARM/Ab stract/PHARM_3323_20150728171657

18. Wulandari YW, Mustofa A. Pengaruh perlakuan penggilingan terhadap rendemen atsiri daun jeruk purut (Citrus hystrix DC) dengan metode destilasi air. JOGLO. 2017;29(1):1-9.

19. Salgueiro L, Martins AP, Correia H. Raw materials: the importance of quality and safety. A review. Flavour and Fragrance Journal. 2010;25:253-71.

20. Gopu C, Aher S, Mehta H, Paradkar A, Mahadik K. Simultaneous determination of cinnamaldehyde, eugenol and piperine by HPTLC densitometric method. Phytochemical Analysis. 2008;19(2):116-21.

21. Ulfah D, Karsa LA. Pengaruh tempat tumbuh dan lama penyulingan terhadap rendemen minyak atsiri rambu atap (Baeckea frustescens L) dengan penyulingan metode perebusan. Jurnal Hutan Tropis Borneo. 2007;08(21):84- 
8.

22. Ravindran P, Nirmal-Babu K, Shylaja M. Cinnamon and cassia: The genus Cinnamomum. Taylor \& Francis eLibrary; 2005. 60-71 p.

23. Gonçalves $\mathrm{R}$ de $\mathrm{A}$, Pinheiro $\mathrm{AB}$, de Oliveira MA, do Nascimento RT, Rosalem PF, Garcia VL, et al. Anatomical characters and chemical profile of leaves of three species in Lauraceae family. Brazilian Journal of Pharmacognosy. 2018;28:1-8.

24. Geng S, Cui Z, Shu B, Zhao S, Yu X, Geng $S$, et al. Histochemistry and cell wall specialization of oil cells related to the essential oil accumulation in the bark of Cinnamomum cassia Presl. (Lauraceae). Plant Production Science. 2012;15(1):1-9.

25. Rehman R, Hanif MA, Mushtaq Z, Mochona B, Qi X. Biosynthetic factories of essential oils: The aromatic plants. Natural Product Chemistry \& Research. 2016;4(4):1-11.
26. Nugraheni KS, Khasanah LU, Utami R, Anandito BK. Pengaruh perlakuan pendahuluan dan variasi metode destilasi terhadap karakteristik mutu minyak atsiri daun kayumanis ( $C$. burmannii). Jurnal Teknologi Hasil Pertanian. 2016;9(2):51-64.

27. Wu X, He J, Xu H, Bi K, Li Q. Quality assessment of cinnamomi ramulus by the simultaneous analysis of multiple active components using High Performance Thin Layer Chromatography and High Performance Liquid Chromatography. Journal of Separation Science. 2014;37(18):2490 8.

28. Yuliarto FT, Khasanah LU, Anandito RBK. Pengaruh ukuran bahan dan metode destilasi (destilasi air dan destilasi uap-air) terhadap kualitas minyak atsiri kulit kayu manis (Cinnamomum burmannii). Jurnal Teknosains Pangan. 2012;1(1):12-23. 